\title{
THE SETTLEMENT PRINCIPLES AND EFFECTIVENESS OF DIVORCE BY MEDIATION OF ISLAMIC CIVIL PERSPECTIVE: A Critical Review of The Supreme Court Regulation
}

\author{
Abdullah Taufik* \\ Faculty of Sharia, State Institute for Islamic Studies, Kediri, Indonesia \\ Email: abtakediri@iainkediri.ic.id
}

* Corresponding author

DOI: 10.21154 /justicia.v18i1.2139

\begin{tabular}{l|l|l}
\hline Received: July 26, 2020 & Revised: Jan 23, 2021 & Approved: May 17, 2021
\end{tabular}

Abstract: Mediation of divorce is expected to be able to suppress the settlement of the case peacefully. In principle, based on the Elucidation of Law Number 1 of 1974 concerning Marriage, the purpose of marriage is to form a happy and eternal family. Therefore it is urgent to find mediation pillars in settlement of divorce cases. To find the idea in response to these problems, three approaches: 1) laws and regulations, by examining them that relate with divorce settlement through mediation in religious courts; Supreme Court Regulation Numb. 1 of 2016, Civil Procedure Code. 2) Conceptual approach, from the view of experts/scholars, is used to find ideas by building concepts and arguments according to the issues to be examined to find the efficiency in the implementation of mediation. 3) Philosophy, studying literacy related to the theme of the study to capture philosophical content in finding the pillars of mediation in the study of Islamic civil law. The findings in this study are the pillars of mediation whose relevance to divorce disputes should be stated are: 1) Essence of Deliberation, to reach an agreement. 2) The essence of mutual forgiveness, to end the dispute. 3) The essence of respecting the rights of others, of avoiding the nature of egoism. 4) The essence of justice, giving equal opportunity to speak to each other so that both parties get the same rights. While the efficiency of the mediation implementation in settlement of divorce can be done by mediating: 1) Regarding the care and education of children, 2) cost of living of ex-wife, 3) guarantee for the maintenance of the joint property after the termination of a marriage.

Mediasi diharapkan mampu menekan penyelesaian perkara penyelesaian secara damai. Pada prinsipnya berdasarkan Penjelasan Undang-Undang Nomor 1 tahun 1974 tentang Perkawinan tujuan perkawinan adalah untuk membentuk keluarga yang bahagia dan kekal. Penurunan tingkat perceraian perlu ditekan, maka dari itu sangat mendesak untuk mencari pilar-pilar mediasi dalam penyelesaian perkara perceraian. Untuk menemukan ide dalam menanggapi permasalahan tersebut digunakan tiga pendekatan: 1) Peraturan perundang undangan, yang berhubungan dengan penyelesaian perceraian melalui mediasi di pengadilan agama; Peraturan Mahkamah Agung No. 1 tahun 2016, Kitab Undang Undang Hukum Acara Perdata. 2) Pendekatan konseptual, dari pandangan para ahli / ulama digunakan untuk menemukan ide dengan membangun konsep dan argumen sesuai dengan masalah yang akan dikaji sehingga dapat ditemukan efektifitas dalam pelaksanaan mediasi 3) Filsafat, mempelajari literasi yang berkaitan dengan tema 
kajian untuk menangkap muatan filosofis dalam menemukan pilar-pilar mediasi dalam kajian hukum perdata Islam. Temuan dalam penelitian ini adalah pilar-pilar mediasi yang relevansinya dengan perselisihan perceraian yang harus dikemukakan adalah: 1) Inti Musyawarah, untuk mencapai kesepakatan. 2) Inti saling memaafkan, untuk mengakhiri perselisihan. 3) Esensi menghargai hak orang lain, menghindari sifat egoisme. 4) Esensi keadilan, memberikan kesempatan yang sama untuk saling berbicara, sehingga kedua belah pihak mendapatkan hak yang sama. Sedangkan efektifitas pelaksanaan mediasi dalam penyelesaian perceraian dapat dilakukan dengan memediasi: 1) Seputar pengasuhan dan pendidikan anak, 2) biaya hidup mantan istri, 3) jaminan pemeliharaan harta bersama pasca pemutusan hubungan perkawinan.

Keywords: Pillar of Mediation; Value of Effectiveness; Settlement of Divorce.

\section{INTRODUCTION}

The Settlement of disputes in marriage becomes the authority of religious courts, especially for those who are Muslim. The dispute in a marriage that is more popularly known as divorce requires the parties that those who want to get a divorce should apply in a court of law with established procedures or civil procedure law, the judicial institutions that authorize to settle divorce are two types; Religious court is intended for people who are Muslim, while general court for those who are non-Muslims.

The Islamic Family Law Literature formulates divorce into two main terms. Namely, Sue's divorce is a legal action of terminating a marriage relationship submitted by a wife. At the same time, the other is Tala's divorce, which is an act of terminating the marriage relationship submitted by a husband. It is determined in Article 39 of Law Number 1 of 1974 Concerning Marriage. “Divorce can only be conducted before a court hearing after the court has tried but failed to reconcile the two parties."

The Settlement of divorce in a religious court through mediation is part of proceeding in a religious court because of the divorce case or civil law. Hence, the settlement follows the civil procedure law in general and other provisions stipulated in the procedural law of the religious court. Settlement of civil cases in a court of law before a panel of judges examines a case must first take mediation as mandated by Article 130 HIR (Het Herziene Inlandsch Reglement), the renewed Indonesian Regulation, and Article 154 Rbg. (Tot Regeling Van Het Rechtsuezen Regulations in De Gewesten Buiten Java En Madura) Procedure Law Regulation for outside Java and Madura", that the judge must first reconcile the parties to the litigation before the case is examined." (article 4 The Supreme Court Regulations, on Mediation Procedures in the Court, paragraph (1) states "All civil disputes submitted to the court include a case of resistance (Verzet) over the Verstek 
decision and a litigation party (Partij Verzet) and a third party (Derden Verzet) against the implementation of decisions that have permanent legal force, must first be sought through Mediation unless otherwise stipulated based on this Supreme Court regulation).

Several Studies of mediation concluded that the mediation had been mandated by the Supreme Court Regulation Numb.1 of 2016 is not efficient and effective in reducing dispute divorce in the Religious Court, as an illustration of the phenomenon of the failure of mediation is Ismiyati`s research in 2018, in Kediri Religious court, it was stated from 723 deforce cases in a religious court, only 148 people that obey the mediation procedure, meanwhile only 4 cases of them were successful. ${ }^{1}$ In Malang Religious Court, in 2018, it was stated that from 542 cases completed through mediation were 63 cases, resulting in a mediation success rate of $11.62 \% .^{2}$ From the phenomena of the mediation process in the Religious Court, few studies on mediation in divorce settlement concluded that the Implementation of Supreme Court Regulations Number 1 of 2016 concerning Mediation Procedures in the Religious Courts was ineffective in resolving divorce disputes.

The standard of success in divorce case mediation is measured by the failure of divorce between husband and wife as manifested by the plaintiff's withdrawal. This provision is complicated to fulfill in settling cases through mediation. Settlement of divorce cases carried out peacefully, and the result of the agreement is divorce (because it is considered maslahah). It is considered contrary to several notions of harmony and peace in a divorce case. ${ }^{3}$ If the divorce rate is still high, the effectiveness of mediation needs to be reviewed and found the correct formulation to reduce the high divorce rate.

Based on the description of the settlement of divorce cases through mediation above, this article will try to contribute thoughts related to the implementation of mediation in resolving divorce cases in the Religious Courts which are focused on; 1 ) How are the pillars of mediation in the perspective of Islamic civil law; 2) How mediation has efficiency values.

The research focused on mediation has so far described the successes and failures in resolving divorce cases, to the conclusion that mediation in resolving divorce cases in the Religious Courts is ineffective because it does not produce the results like the following research;

\footnotetext{
Siti Nur Ismiyati, “Efektifitas Implementasi Mediasi Dalam Perceraian, Di PA Kota Kediri Tahun 2018” (IAIN Kediri, 2019), v.

2 Saiful Karim, "Evaluasi Perjalanan Proses Mediasi Di Pengadilan Agama Malang Selama Tahun 2018," n.d.

3 Muhammad Saifullah, "Efektivitas Mediasi Dalam Penyelesaian Perkara Perceraian Di Pengadilan Agama Jawa Tengah," Al-Ahkam 25, no. 2 (2015): 192, https://doi.org/10.21580/ahkam.2015.25.2.601.
} 
Article Tb. Ahmad Ulfi in $2016^{4}$ the title "Effectiveness of Mediation in Preventing Divorce and its Relation to the Supreme Court regulations Numb. 1 of 2008." The issues raised in this article are; 1 ) How is the Religious court of Serang's efforts in maximizing mediation to resolve divorce, 2) How is mediation links with Supreme Court regulations Numb. 1 of 2008, the study results stated that mediation carried out by a religious court of Serang was considered ineffective. This was based on the assumptions of 135 cases that had been successfully mediated with only 3 cases.

Salamah Article 2013, ${ }^{5}$ the title "Urgency of Mediation in Divorce Cases in the Religious Courts," the issues raised in this article are 1) How is the urgency of mediation in resolving divorce disputes, 2) What is the role of the family as Tahkim that mediates divorce disputes, while the results of the review of the article conclude that mediation is an urgent matter done to resolve dispute divorce, that before the divorce case goes to trial should be appointed tahkim taken from the family of each of the parties to mediate the case Divorce to be reconciled.

The research above gives a negative impression on the implementation of mediation so that mediation does not benefit the settlement of divorce cases. Therefore it is important to give fresh thought to mediation. The study in this article tries to find the mediation pillars and their efficiency in resolving divorce cases as an essential contribution expected to eliminate the negative impression about mediation.

\section{UNDERSTANDING OF MEDIATION}

Mediation is a way to clarify an issue that ultimately the parties have trust in each party. ${ }^{6}$ Here are some definitions of mediation according to experts:

1. Laurence Bolle, "Mediation is a decision-making process in which a mediator assists the parties. The mediator attempts to improve the decision-making process and assists the parties the reach an outcome to which of them can assent. $^{7}$

J. Folberg and A. Taylor ".... The process by which the participants, together with the assistance of neutral persons, systematically isolate the dispute to develop options, consider alternatives, and reach a consensual settlement that will accommodate their needs. ${ }^{8}$

$4 \quad$ Tb. Ahmad Ulfi, “EFEKTIVITAS MEDIASI DALAM MENCEGAH PERCERAIAN DAN KAITANNYA DENGAN PERATURAN MAHKAMAH AGUNG NOMOR 1 TAHUN 2008 (Studi Di Pengadilan Agama Serang)," Bil Dalil 1, no. 1 (2016): 20.

5 Yayah Yarotul Salamah, "Urgensi Mediasi Dalam Perkara Perceraian Di Pengadilan Agama," AHKAM : Jurnal Ilmu Syariah 13, no. 1 (2013): 85, https://doi.org/10.15408/ajis.v13i1.953.

6 Mardalena Hanifah, "Kajian Yuridis : Mediasi Sebagai Alternatif Penyelesaian Sengketa Perdata Di Pengadilan," Jurnal Hukum Acara Perdata ADHAPER 2 (2016): 1.

7 Laurence Bolle, Mediation: Principles, Proscess, and Practice (New York, 1996), 1.

8 J. folberg et. al, Mediation: Comprehensive Guide in Resolving Conflict without Litigation (Cambridge: 
2. While according to Basuki Rekso, Supreme Court Judge, "Mediation is controlled negotiation. ${ }^{9}$

3. Legally of mediation can be found on the Supreme Court Regulation Number 1 of 2016 about mediation procedure in the Court on the general provisions of Article: (1) Mediation is a way of settling disputes through the negotiation process to obtain the agreement parties, assisted by the Mediator.

Basically, as a form of Alternative Dispute Resolution (ADR), there are various definitions of mediation put forward by legal experts. However, in general, many admit that mediation is a process for resolving disputes with the help of third parties. ${ }^{10}$

In this case, the author considers mediation based on the Supreme Court Regulation No.1 of 2016 concerning the procedures for mediation in court to understand based on being a comparison. The implementation of Mediation in the Supreme Court refers to the Supreme Court Regulation Number 1 of 2016 concerning the procedures for mediation in court.

\section{UNDERSTANDING OF THE MEDIATION PILLARS}

The pillars of mediation accumulate in one fundamental principle born from the crystallization of the value of peace in Islam, regarding these basic principles as argued by some Muslim thinkers. First, Razi Ahmad, according to him that Islam has laid down the principles of the Qur'an regarding the settlement of peace disputes, among others; The value of unity, the power of love from the creator, responsibility for all actions, respect for the rights of others, and openness to the views of others. Second, George Irani and Nathan C. Fank found several principles of peace in the Al-Qur'an, which can resolve the conflict; justice, equality, universality, human dignity, social strengthening by doing good, empathy, and caring for others. Third, Abdul Ghaffar Khan argues that peace values that can be used are; guidelines in dispute resolution, charity, faith, and compassion. At the same time, those directly related to conflict resolution are; value, fairness, good deeds, mercy, and wisdom. Fourth, Muhammad Abu Nimer discovered several principles in dispute resolution based on the Koran and was practiced by the Prophet Muhammad.

The role of judges in trying to settle cases peacefully is significant. Peace decisions have a perfect meaning for society in general for seekers of justice. The dispute is entirely resolved, the resolution is fast, the cost is low, and the cost is cheap. ${ }^{11}$

Cambridge University Press, 1984), 7.

Basuki Rekso, Modul Pelatihan Mediasi,Jimly (Surabaya: Jimly School Of Law, 2018).

10 Abdul Halim Talli, "Mediasi Dalam Perma Nomor 1 Tahun 2008," Jurnal Al-Qadāu 2, no. 1 (2015): 77.

11 Stevana Ameliana Kusen, “Lex Crimen Vol. V/No. 6/Ags/2016," Hakekat Keberadaan Mediasi Sebagai Alternatif Penyelesaian Sengketa Perdata Di Pengadilan Negeri V, no. 6 (2016): 17. 
Abdullah Taufik, The Settlement Principles and Efectiveness of Divorce by Mediation ...

\section{DEFINITION OF EFFECTIVENESS}

In this study, the definition of effectiveness refers to the theory of legal effectiveness according to Suryono Soekanto. According to him, the law is a rule of human behavior or regulating human behavior. The law is said to be effective if the legal authority can influence human behavior. Society, according to its objectives, the effectiveness of the law will be influenced by five factors, namely; 1. The legal factor itself (Law) 2. Law enforcement factors, namely the parties that form or implement the law 3. Facilities or facilities that support law enforcement 4. Community factors, namely the environment in which the law applies and can be applied 5. Cultural factors, namely, work, creativity, and taste, are based on the human initiative in social life.

Legal effectiveness can be defined as the ability of the law to create or give birth to a situation or situation that is desired by law or expected by law. ${ }^{12}$ Then the effectiveness of mediation for the settlement of divorce disputes can be seen whether the mediation can resolve the problems that occur and reconcile the parties in dispute. Regardless of the factors underlying the emergence of divorce, the role of the mediator is significant in guiding and seeking peace between the two parties. Then the effectiveness of Mediation for the settlement of divorce disputes can be seen whether the mediation can resolve the problems that occur and reconcile the parties in dispute. Regardless of the factors underlying the emergence of divorce, the role of the mediator is crucial in guiding and seeking peace between the two parties.

Legal effectiveness is an activity that shows a general problem formulation strategy, namely a comparison of legal reality with legal ideals. In particular, the level between law in action and law, in theory, is seen. In other words, this activity will show the link between law in action and law in theory. The effectiveness of law means examining the rule of law that must meet the requirements, namely to apply juridically, sociologically, and philosophically. ${ }^{13}$

\section{PILLARS OF MEDIATION IN THE PERSPECTIVE OF ISLAMIC CIVIL LAW}

Mediation is an alternative dispute resolution with a noble philosophical basic because: First, it is intended to maintain the parties' relationship in the long term (Prospective). Second, create psychological calm and satisfaction for the parties to the dispute because no one feels defeated by one another. The resulting agreement is seen as more favorable than a losing win situation. Third, as an

12 W. Yudho; H. Tjandrasari, Efektivitas Hukum Dalam Masyarakat (Jakarta: Majalah Hukum dan pembangunan, UI Press, 1987), 59.

13 Djaenab Djaenab, “Efektifitas Dan Berfungsinya Hukum Dalam Masyarakat," Ash-Shahabah 4, no. 2 (2018): 151. 
alternative forum following the nature and character of disputes, especially dispute resolution, maintain "Social Harmony." So that social harmony is a top priority, because until whenever humans will always live in a community which has interdependence with one another and would not be possible to live alone, free from them. Therefore, social relationships are long-term relationships that require the maintenance and commitment of a community.

\section{SCOPE OF MEDIATION CASE}

Those litigants must do mediation before the case is checked as stated in the Supreme Court Regulation Numb. 1 of 2008, that is not gone through a mediation process violation to the provisions of Article 130 (HIR) / 154 (Rbg.) Moreover, the verdict was declared null and void. As a Project pilot of the Supreme Courtappointed four courts, namely the South Jakarta District Court, Depok District Court, Bogor District Court, Bandung District Court, to be pioneer before issuing the Supreme Court Regulation No 1 of 2016 concerning Mediation Procedures in the court, related mediation in the court according to the regulation use the term obligations to act mediation in goodwill mediation. It means that the parties involved in the mediation process must be well-meaning. It is intended that the mediation process can be implemented and can run well.

On the other hand, the mediation process cannot run well due to the lack of sound elements. The lack of good faith motives can be indicated as follows;

1. Did not attend the Mediation Process even though he had been summoned twice in a row,

2. Present at the first mediation meeting, but then not present even though he has been called twice in a row,

3. Do not repeatedly attend, so that interfere with the mediation schedule,

4. Not submitting or not responding to case resumes,

5. Not signing a peace agreement.

Not all cases that go to court can be mediated, but some exceptions cannot be mediated because it is determined otherwise by the laws and regulations. The categories are;

1. cases that must take Mediation are all dispute cases submitted to the court, including cases of resistance (Verzet) for decisions (Verstek) and litigation resistance (Partij Verzet), as well as third parties (Derden Verzet) against the implementation of decisions that have permanent legal force,

2. and then Cases exempt from settlement through mediation are:

a) Dispute cases for which hearings are determined for a settlement period includes; 
Abdullah Taufik, The Settlement Principles and Efectiveness of Divorce by Mediation ...

1) disputes are resolved through the Commercial Court procedures,

2) disputes are resolved through Industrial Relations Court procedures,

3) objection to the decision of the Business Competition Supervisory Commission,

4) objections to the decision of the Consumer Dispute Resolution Agency,

5) Application for Cancellation of Arbitration Award,

6) the objection of the decision of the Information Commission,

7) settlement of political party disputes,

8) disputes are resolved through simple lawsuit procedures,

9) other disputes where the examination at the hearing is determined to have a grace period,

b) Dispute where the examination is carried out without the presence of the plaintiff or defendant who has been appropriately summoned,

c) Counterclaim (Reconvention) and the entry of a third party in a case (Intervention),

d) Disputes regarding marriage prevention, rejection, cancellation, and approval,

e) Disputes brought to court after an out-of-court settlement through mediation with the help of a certified mediator registered in the local court. However, they declared unsuccessful based on statements signed by the parties and certified mediator.

\section{LEGAL CONSEQUENCES OF MEDIATION AGREEMENTS}

The mediation process that is running can be whether successful or unsuccessful, so if there is an agreement in the mediation process, the following things will be done;

1. The parties assisted by the mediator must formulate a written agreement in the peace agreement, which ends with the signing of the parties and the mediator,

2. Avoiding provisions that are contrary to law, public order, and/decency, cause third party losses, or the agreement cannot be implemented,

3. Make a written statement containing the parties' agreement if their attorneys terminate the mediation,

4. A peace agreement can be submitted by the judge of the case examiner to be included in the peace certificate,

5. The peace agreement must include the withdrawal of the lawsuit if the parties do not want the deed of peace, 
6. Report on the success of mediation to the Case Inspector by attaching a peace agreement.

The result to be achieved in mediation is the achievement of an agreement between the parties related to the provisions of dispute resolution, which are realized in a text and arranged in a peace deed, as in the general provisions of Article 1 of the Supreme Court Regulations No 1 of 2016, number: (8) which states that the peace agreement is an agreement on the results of mediation in the form of a document containing the dispute resolution provisions signed by the parties and the mediator.

The success of mediation in divorce cases so far has only been measured by whether mediation efforts can stop a divorce or not. So, if the mediation effort can restore the integrity of the household, said the mediation is succeeded. Otherwise, if the mediation effort was unable to restore the integrity of the household, it was said to have failed. Such perception certainly gives a negative nuance to the implementation of mediation in settlement of divorce cases. Mediation mandated by the Supreme Court Regulation No 1 of 2016 does not produce efficient results.

For this reason, it is necessary to contribute positive thinking to the implementation of mediation, especially in the area of the divorce settlement, so that it has meaningful benefits. However, it is difficult to reconcile between two parties at the end of a divorce. At least mediation can help ease the burden that will arise after the divorce, such as the burden cost of living ex-wife, caring for children to adulthood, and the cost of education. Studies of the value of conflict resolution in the early history of the development of Islam provide much inspiration that should be appreciated then can be appointed as an essential pillar in the implementation of mediation.

\section{MEDIATION APPROACH IN ISLAMIC CIVIL LAW}

Manifestation of mediation efforts is the occurrence of peace between the disputing parties. Islam is very appreciative of peaceful efforts because, after all, peace is one of the basic human needs only realized through harmonious interaction between humans. When humans are disputed naturally, the signal of human harmony interaction begins to crack. That is why hormonal interactions are essential. Many of the values of Islamic civilization that teach peace are:

1. Islam as a religion of peace is relevant to one of the names of Allah collected in Asma-Al husna "Al-Salam" (the most peaceful),

2. Peace is the teachings of the prophet in the history of Islamic civilization, as the prophet forbids to kill kafir dhimmi (non-Muslims) who have made agreements with Muslims and not contribute to them to fight other Muslims. 
Guidance relating to peace, as his word in the Qur' an Surah An-Nisa verse 35: "And if you are worried that there will be a dispute between the two, then send a peacemaker from a male family and a peacemaker from a female family. If both (the peacemakers) intend to make improvements, surely Allah will give taufiq to the husband and wife. Truly, Allah is most conscientious, all-knowing."

Settlement of cases through mediation following Islamic law means that mediation is seen from the theory of equality with tahkim. Dispute resolution through the tahkim institution was practiced during the caliphate of Ali bin Abu Talib with Muawiyah. This means that the dispute between the two parties is settled amicably through negotiation (deliberation) of the two parties or negotiations between the two parties.

The deliberation activity is a crucial element for both parties in a court case to conduct mediation facilitated by a mediator appointed by the Chairperson of the Panel of Judges who hears the case. In the Islamic world, dispute resolution through mediation is quite joint in practice. Mediation is one method used to find the best solution in solving problems, including currently being mediated in the Religious Courts. The results achieved through a deliberation process involving experts in the field are much better than just thinking about one person. ${ }^{14}$

From this event, it can be taken that peace is needed in principle, peace, patience, respect for others, commitment, and proactivity to resolve disputes. ${ }^{15}$ What can be learned from the history of mediation in Islamic law is that in the current context, the integration of mediation in court proceedings, including the Religious Courts, is not against Islamic law. Therefore, mediation must be optimized through efficiency and effectiveness in the Religious Courts to achieve the maximum possible peaceful settlement. Whatever the case, in the context of civil or divorce, peaceful dispute resolution is the settlement with the highest benefit value compared to other dispute resolution methods in court.

\section{PRINCIPLES AND VALUES OF PEACE IN ISLAM}

In the research of George E. Irani and Nathan C. Funk, it was explained that the values and principles of peace that can be used in conflict resolution are as follows: the principle of justice, the principle of equality, the universal principle, and human dignity, social reinforcement by doing good, empathy and pay attention to other people ${ }^{16}$ in Syahrizal Abbas`s opinion, the values and principles of justice in Islam can be classified systematically as follows.

14 Wirhanuddin, "Mediasi Perspektif Hukum Islam : Studi Kasus Di Wilayah Pengadilan Tinggi Agama Makassar," Jurnal Diskursus Islam 1, no. 2 (2013): 244.

15 Syahrizal Abbas, Mediasi Dalam Perspektif Hukum Syariah (Jakarta: Kencana, 2009), 168.

16 George F. Irani et. All, Ritual Of Reconciliation, Arab Islamic Perspectif (New York: University Press Of America, 2007), 177-80. 
1. Values that underlie the philosophy of dispute resolution; values of glory, honor, press, brotherhood and fellowship, values that the parties must own to the dispute,

2. the description of these values are; Tolerant values, respect for the rights of others, openness, respectful, and a willingness to forgive, the value that the parties must hold to the dispute accumulation of values that must be adhered parties, justice, courage, generous, confident, wisdom, advice, empathy and pay attention to other people,

3. value to be the end goal of dispute resolution, the underlying value of the ultimate goal of dispute resolution, glory, social justice, good deeds, brotherhood, and human dignity. ${ }^{17}$

The scope of jurisdiction is comprehensive. This jurisdiction also extends to the issue of divorce in the sense of reconciling the parties so as not to divorce and other civil disputes. The Religious Courts have jurisdiction to make peace in the sense that the litigants do not divorce. Religious judges who examine and adjudicate the case are still obliged to make efforts so that the disputing parties get peace. In the event of an agreement, the plaintiff shall withdraw the case.

Mediation in Islamic law has been formulated in such detail in the concept of tahkim. This proves the conformity of Islamic law with the needs of modern humanitarian law. As a non-formal institution, tahkim will continue to exist if the community still upholds the values of brotherhood and togetherness, manifested in legal awareness to ensure justice. To ensure its existence, clear regulations on the tahkim are needed. ${ }^{18}$

The purpose of Islamic law is not limited to material fields which are temporary, nor to matters of mere formal nature. However, Islamic law considers various factors such as individual factors, community factors, and human factors about one another to realize the benefit. The benefit approach with the basic theory of maqasid al-syar'iyah maintains offspring and property (obtained during marriage) as in the dharuriyyah principle. I am resolving family law disputes in family cases between husband and wife divorced through a peace agreement through a mediation process, closing some of the possibility of family breakdown.

Thus, the principles of peace in Islam must be maintained by the Mediator who resolves family problems. This is the principle and goal of Islamic law to resolve problems peacefully.

Abbas, Mediasi Dalam Perspektif Hukum Syariah.

18 Ahmed Shoim El-Amin, “Konsep Mediasi Dalam Hukum Islam," Al-Munqidz: Jurnal Kajian Keislaman 2, no. 1 (2013): 29. 


\section{The Effectiveness Value of Mediation Divorce}

Mediation is an alternative form of dispute resolution that has power so that mediation is an option that those in dispute can use. ${ }^{19}$ Every dispute resolution in court obliges peace efforts firstly as a manifestation of peace efforts is through mediation, so mediation become the first stage in the litigation process in court, with the mediation is expected to be a media of peace from the parties who litigate, in the end, the parties can clarify the problem that becomes triggers on a dispute under the guidance of a mediator, and the ending of agreement can produce a win-win solution (mutual benefit) because mediation is based on a consensus approach and the consensus of the parties ${ }^{20}$.

The success of mediation can also be seen from the effectiveness of the implementation of mediation which rests on the professionalism of the mediating judge in carrying out the mediation process (expertise in formal and material law, as well as expertise in the psychological field), the mediator judge must be certified, there is a clear legal substance or regulation and to make peace in earnest. All mediator judges must have a mediator certificate to ensure that the mediator has the skills and abilities to resolve cases with excellent and effective techniques and that mediation can be successful. ${ }^{21}$

It becomes a fundamental problem if the parties in a case do not have the desire or willingness to mediate. It will cause an ineffective condition or situation to have to mediate. However, fundamentally it needs to be understood that the ability of the parties to see an alternative in solving the case at hand is usually limited, so it is necessary to be encouraged to be able to see and know ways that were unthinkable and unimaginable beforehand. With these conditions, it is hoped that the parties will be able to find and see the positive side of the mediation process offered.

Conflicts that go to the court must be handled professionally, especially those related to family law, such as divorce cases combined with cases of joint property, child care, livelihoods, and inheritance disputes. ${ }^{22}$ According to Islam, the concept of the family is not substantially different from the concept of dispute resolution through mediation. Only at specific points that give more emphasis to the implementation. Mediation is a problem-solving negotiation process in which the counselor acts as a neutral or impartial party to help alleviate the problem at hand.

19 Sri Puspitaningrum, "Mediasi Sebagai Upaya Penyelesaian Sengketa Perdata Di Pengadilan," Spektrum Hukum 15, no. 2 (2018): 291, https:/ / doi.org/10.35973/sh.v15i2.1121.

20 Asmawati, “Dosen Hukum Perdata Fakultas Hukum Univ. Jambi.,” Ilmu Hukum 6, no. 4 (1999): 57.

21 Dian Maris Rahmah, "Optimalisasi Penyelesaian Sengketa Melalui Mediasi Di Pengadilan," Jurnal Bina Mulia Hukum 4, no. 1 (2019): 7, https:/ / doi.org/10.23920/jbmh.v4i1.174.

22 Wirhanuddin, "Mediasi Perspektif Hukum Islam : Studi Kasus Di Wilayah Pengadilan Tinggi Agama Makassar." 
Supreme Court Regulation No. 1 of 2016 article 7 regulates the obligation to carry out mediation in good faith. The parties involved in the mediation process must have good faith so that with good faith, the mediation process can be carried out and run well. Indicators that state the parties are not in good faith in carrying out the mediation, namely:

The first new thing is the obligation of the parties to attend mediation, even if they are not accompanied by a Legal Counsel. In terms of facilitating this implementation, Supreme Court Regulation No.1 of 2016 facilitates the parties by making it easier for the parties to mediate through visual communication media (Article 5 paragraph (3) of Supreme Court Regulation No 1 of 2016). It considers the presence of the parties through audio-visual communication as a direct presence. (Article 6 paragraph (2) Perma Number 1 of 2016).

If the parties cannot attend, the reasons for absenteeism must be following a valid reason for their absence (Article 6 paragraph (3) of Perma Number 1 of 2016). The following are valid reasons for the parties not to attend the mediation process (Article 6 paragraph (4) Perma Number 1 of 2016):

a) A health condition that makes it impossible to attend a mediation meeting based on a doctor's certificate;

b) Under interdiction;

c) Has a residence, residence, or position abroad; or

d) Carrying out state duties, professional demands, or jobs that cannot be left behind.

Furthermore, if a party is absent without valid reasons during the mediation process, that party will not have good faith. Perma No.1 of 2016 regulates the legal consequences when a party is declared lousy faith in the mediation process. This is an additional provision that has not been regulated in Perma Number 1 of 2008, as the author will describe further in the next paragraph. The obligation to attend mediation is one of the efforts to make negotiations run effectively and efficiently due to the direct participation of the parties in the mediation process.

The implementation of mediation in the presence of parties who are not in good faith has a legal impact on the case examination process. In this case, it can be seen from the parties who are not in good faith.

Provisions regarding the good faith of the parties who take mediation are regulated in Article 7 of Perma Number 1 of 2016. Unlike the previous Perma, Perma Number 1 of 2016 qualifies several things that cause one of the parties or parties and/or their attorneys to be declared to have no intention good (Article 7 paragraph (2) Perma Number 1 of 2016), namely: 
a) The absence of one of the parties or the parties after being summoned in row 2 (two) times in a row in the Mediation meeting without a valid reason;

b) Attended the first mediation meeting but never attended the next meeting even though he had been appropriately summoned 2 (two) times in a row without valid reason;

c) Repeated absences that interfere with the Mediation meeting schedule without a valid reason;

d) Attend mediation meetings, but do not submit and/or do not respond to other parties' Resume of Cases; and/or

e) Do not sign the agreed conciliation concept without valid reasons.

The legal consequence of a party or parties with bad faith in the mediation process is the obligation to pay mediation fees. However, if the party with bad faith is the plaintiff, the lawsuit will also be declared unacceptable by the Case Examining Judge (Article 22-23 of Perma No.1 of 2016). Furthermore, for the decision stating that the lawsuit cannot be accepted and the imposition of the obligation to pay mediation fees, no further legal remedies can be made (Article 35 paragraph (2) Perma Number 1 of 2016). ${ }^{23}$

The legal consequence of the inability to accept the plaintiff's claim is one of the efforts implemented in Perma No.1 of 2016 to trigger the plaintiff's seriousness to settle the case even though it is still in the mediation stage.

Obligations of legal counsel in Article 18 Legal attorneys are obliged to assist the Parties in exercising their rights and obligations in the Mediation process. The obligations of a legal attorney as referred to in paragraph (1) include:

a. Deliver the explanation of the Case Examining Judge as referred to in Article 17 paragraph (7) to the Parties;

b. Encouraging the Parties to take an active direct role in the Mediation process;

c. Help the Parties identify their needs, interests, and proposed dispute resolution during the Mediation process;

d. Assist the Parties to formulate a Peace Agreement plan and proposal if the Parties reach an agreement;

e. Explain to the parties the obligations of a legal attorney.

Suppose the Parties cannot attend based on valid reasons as referred to in Article 6 paragraph (4) Perma No. 01 of 2016. In that case, the attorney can represent the Parties to carry out Mediation by showing an extraordinary power of attorney containing the legal power of attorney to make decisions. Lawyers are acting on behalf of the Parties. As referred to in paragraph (3), must participate in

23 Damar Ariotomo, "Harapan Optimalisasi Proses Mediasi Pasca Perma Nomor 1 Tahun 2016 | Adnan Buyung Nasution And Partners," 2016. 
the Mediation process in good faith and in a manner that does not conflict with other parties or their legal attorneys. ${ }^{24}$

Perma No. 01 of 2016 provides emphasis and enforcement to uphold the principles of mediation. In principle, Perma No. 01 of 2016 does not conflict with the pillars of Islamic mediation. However, the data shows that the high divorce rate raises whether Perma No. 01 of 2016 runs effectively. According to Anthony Allot, he stated that the effectiveness of a law is that the law will be effective if the purpose of its existence and its application is to prevent unwanted actions and eliminate chaos. ${ }^{25}$

In this case, the Mediator, as one of the implementers of Perma No. 1 of 2016, has a significant role in the mediation process, so it must have special skills and expertise, as mandated by Article 13 of Supreme Court regulation No. 1 of 2016. Mediator resource optimization is an efficient application of mediation to be carried out well and is expected to reduce the high divorce rate. So, in this case, the effectiveness must be encouraged by the efficiency of the Mediation system so that legal objectives can be achieved.

\section{Pareto Efficiency Approach}

Pareto efficiency states that something is said to be efficient if it can give happiness to the parties without giving a loss to either party ${ }^{26}$ concept of Pareto efficiency will make many significant contributions, especially for mediators as mediators in religious courts in resolving divorce disputes, because mediation will always be directed by taking themes that are beneficial to both parties during the mediation process so that the mediation will end with favorable results and happy both parties to the dispute.

By juridical normative that settlement of divorce through mediation items and themes have been determined under the guidelines of the Supreme Court Regulation No 1/2016 concerning the mediation meeting material; a. negotiation material is not limited to posita and petitum claim, b. In the event of a mediation agreement outside the provisions of the posita and petitum, the plaintiff changes the suit by including the agreement in the claim. This provision gives direction to the mediator who carries out mediation is required to be creative innovative in addressing the ongoing process of mediation, so that if the process of returning the integrity of the household is deadlocked, the parties must be brought to

24 “Peraturan Mahkamah Agung Republik Indonesia No 1 Tahun 2016 Tentang Proseur Mediasi Di Pengadilan" (n.d.).

25 H.S; Erlis Septiana Nurbani Salim, Penerapan Teori Hukum Pada Tesis Dan Disertasi, Edsis Pertama, Ctk Kesatu, (Jakarta: Rajawali Press, 2013), 303.

26 Tomasz P. Krzeszowski, Contrasting Languages: The Scope of Contrastive Linguistics, Contrasting Languages: The Scope of Contrastive Linguistics, 2011, https://doi.org/10.1515/9783110860146; J. folberg et. al, Mediation: Comprehensive Guide in Resolving Conflict without Litigation. 
another item, for example discussing the legal consequences to be borne by both parties after the religious court decides the divorce decision. It is done to take advantage of precious moments and try to avoid waste of time, to spend energy that is devoted during the mediation process, so that the mediation of divorce settlement ends with the satisfaction of each party, without the existence of one party harmed, under the principle of Pareto efficiency, related to mediation in divorce that themes can be discussed are as stated in Government Regulation number 9, in 1975, that divorce process between husband and wife cannot be used as an excuse for husbands to neglect his duty to provide a living for his wife and his children as well as for the education of his children who are assigned responsibility to both parents. As described in Article (24) follows:

a. During the divorce proceedings at the plaintiff's request or the defendant or based on consideration of the dangers that may be caused, the Court may permit the husband and wife not to live in one house.

b. During the divorce proceedings at the request of the plaintiff or defendant, the Court may: determine the livelihood that the husband must bear, determine the things that need to ensure the care and education of children, determine the things that are necessary to guarantee the maintenance of the goods which are the joint rights of the husband and wife or the items which are the rights of the husband or the items which are the wife's rights.

Article: (41) of Law No 1 in 1974 determines the legal consequences after divorce;

a. Both the mother or father is still obliged to look after and educate their children, based solely on the interests of the child; when there is a dispute over the possession of children, the Court gives its decision;

b. The father is responsible for all the maintenance and education costs that the child needs; when the father, in reality, can not fulfill these obligations, the Court can determine that the mother shares the costs;

c. The court may require the ex-husband to provide living expenses and/or determine an obligation for the ex-wife.

In realizing the objectives of a simple, fast, and low-cost judiciary through an effective and efficient judiciary, the Supreme Court as the highest judicial administrator in Indonesia, has begun to devise several methods to shorten the dispute resolution process in court. One of these ideas is to optimize the mediation institution in civil cases. It is hoped that the integration of mediation into the court proceeding process is expected to be an effective instrument in overcoming the problem of case accumulation in the Court and strengthening and maximizing 
the function of non-judicial institutions for dispute resolution in addition to court processes that are adjudication. ${ }^{27}$

So, mediation, the basic principle of Islamic law in resolving civil disputes, is an efficient step. For its implementation, it needs to be optimized again with various formulations so that the mediation can run effectively.

\section{CONCLUSION}

Mediation is an urgent matter to be carried out in the stage of examining divorce cases at trial because the mediation stage is a mandate in the civil procedural law of religious courts or general courts so that the success or failure of mediating divorce disputes is not the most important measure that the mediation stage must be passed. The built-in system Supreme Court Regulation No. 1 of 2016 has reasonable goals, but it is not easy to realize peace efforts. The author takes an example such as affirming the obligation of the principal or the litigant to be present directly to carry out Mediation. If the party in the case is not present in person, it is considered not to have good faith and may result in the Court's decision, which is unacceptable. This needs to be accompanied by the efficiency of the Mediation system by optimizing human resources, namely the Mediator's ability. Thus Mediation in Court can run effectively.

Regarding the efficiency value of a Mediation in a divorce settlement is very important because, after all, mediation requires costs, energy, time, and concentration, not to mention that if it is predicted that the mediation will fail, it will undoubtedly harm the parties concerned; The parties to the dispute, the mediator, and the court, to avoid this dire picture, can meditate on certain items such as discussing the responsibility for the maintenance and education of children, supporting the wife during the divorce process, determining joint assets and assets of each.

\section{REFERENCES}

Abbas, Syahrizal. Mediasi Dalam Perspektif Hukum Syariah. Jakarta: Kencana, 2009. All, George F. Irani et. Ritual Of Reconciliation, Arab Islamic Perspectif. New York: University Press Of America, 2007.

Amarini, Indriati. "Penyelesaian Sengketa Yang Efektif Dan Efisien Melalui Optimalisasi Mediasi Di Pengadilan." Jurnal Kosmik Hukum 16, no. 2 (2016): 1-20.

Asmawati. “Dosen Hukum Perdata Fakultas Hukum Univ. Jambi." Ilmu Hukum 6, no. 4 (1999).

27 Indriati Amarini, "Penyelesaian Sengketa Yang Efektif Dan Efisien Melalui Optimalisasi Mediasi Di Pengadilan," Jurnal Kosmik Hukum 16, no. 2 (2016): 93. 
Abdullah Taufik, The Settlement Principles and Efectiveness of Divorce by Mediation ...

Damar Ariotomo. "Harapan Optimalisasi Proses Mediasi Pasca Perma Nomor 1

Tahun 2016 | Adnan Buyung Nasution And Partners," 2016.

Djaenab, Djaenab. "Efektifitas Dan Berfungsinya Hukum Dalam Masyarakat." Ash-Shahabah 4, no. 2 (2018): 148-53.

El-Amin, Ahmed Shoim. "Konsep Mediasi Dalam Hukum Islam." Al-Munqidz: Jurnal Kajian Keislaman 2, no. 1 (2013): 21-30.

Hanifah, Mardalena. "Kajian Yuridis : Mediasi Sebagai Alternatif Penyelesaian Sengketa Perdata Di Pengadilan." Jurnal Hukum Acara Perdata ADHAPER 2 (2016).

J. folberg et. al. Mediation: Comprehensive Guide in Resolving Conflict without Litigation. Cambridge: Cambridge University Press, 1984.

Krzeszowski, Tomasz P. Contrasting Languages: The Scope of Contrastive Linguistics.

Contrasting Languages: The Scope of Contrastive Linguistics, 2011. https:/ / doi. org/10.1515/9783110860146.

Kusen, Stevana Ameliana. “Lex Crimen Vol. V/No. 6/Ags/2016." Hakekat Keberadaan Mediasi Sebagai Alternatif Penyelesaian Sengketa Perdata Di Pengadilan Negeri V, no. 6 (2016): 14-22.

Laurence Bolle. Mediation: Principles, Proscess, and Practice. New York, 1996.

Peraturan Mahkamah Agung Republik Indonesia No 1 Tahun 2016 tentang Proseur Mediasi di Pengadilan (n.d.).

Puspitaningrum, Sri. “Mediasi Sebagai Upaya Penyelesaian Sengketa Perdata Di Pengadilan." Spektrum Hukum 15, no. 2 (2018): 275. https:// doi. org/10.35973/sh.v15i2.1121.

Rahmah, Dian Maris. “Optimalisasi Penyelesaian Sengketa Melalui Mediasi Di Pengadilan." Jurnal Bina Mulia Hukum 4, no. 1 (2019): 1. https:/ doi. org/10.23920/jbmh.v4i1.174.

Rekso, Basuki. Modul Pelatihan Mediasi, Jimly. Surabaya: Jimly School Of Law, 2018.

Saiful Karim. “Evaluasi Perjalanan Proses Mediasi Di Pengadilan Agama Malang Selama Tahun 2018," n.d.

Saifullah, Muhammad. "Efektivitas Mediasi Dalam Penyelesaian Perkara Perceraian Di Pengadilan Agama Jawa Tengah." Al-Ahkam 25, no. 2 (2015): 181. https:/ / doi.org/10.21580/ahkam.2015.25.2.601.

Salamah, Yayah Yarotul. “Urgensi Mediasi Dalam Perkara Perceraian Di Pengadilan Agama." AHKAM: Jurnal Ilmu Syariah 13, no. 1 (2013): 81-88. https://doi.org/10.15408/ajis.v13i1.953.

Salim, H.S; Erlis Septiana Nurbani. Penerapan Teori Hukum Pada Tesis Dan Disertasi, Edsis Pertama, Ctk Kesatu,. Jakarta: Rajawali Press, 2013.

Siti Nur Ismiyati. "Efektifitas Implementasi Mediasi Dalam Perceraian, Di PA Kota Kediri Tahun 2018." IAIN Kediri, 2019. 
Talli, Abdul Halim. “Mediasi Dalam Perma Nomor 1 Tahun 2008.” Jurnal Al-Qadāu 2, no. 1 (2015): 76-93.

Tjandrasari, W. Yudho; H. Efektivitas Hukum Dalam Masyarakat. Jakarta: Majalah Hukum dan pembangunan, UI Press, 1987.

Ulfi, Tb. Ahmad. “Efektivitas Mediasi Dalam Mencegah Perceraian dan Kaitannya Dengan Peraturan Mahkamah Agung Nomor 1 Tahun 2008 (Studi Di Pengadilan Agama Serang)." Bil Dalil 1, no. 1 (2016): 20.

Wirhanuddin. "Mediasi Perspektif Hukum Islam: Studi Kasus Di Wilayah Pengadilan Tinggi Agama Makassar." Jurnal Diskursus Islam 1, no. 2 (2013): 231-53. 